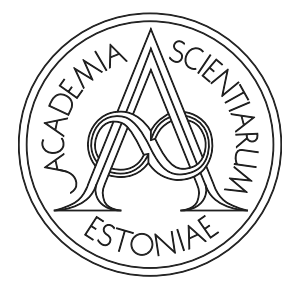

Proceedings of the Estonian Academy of Sciences, $2021,70,4,374-382$

https://doi.org/10.3176/proc.2021.4.02

Available online at www.eap.ee/proceedings

MANUFACTURING

ENGINEERING

\title{
Advancement in production engineering education through Virtual Learning Factory Toolkit concept
}

\author{
Kashif Mahmood ${ }^{\mathrm{a}^{*}}$, Tauno Otto ${ }^{\mathrm{a}}$, Vladimir Kuts ${ }^{\mathrm{a}}$, Walter Terkaj ${ }^{\mathrm{b}}$, Gianfranco Modoni ${ }^{\mathrm{b}}$, \\ Marcello Urgo ${ }^{\mathrm{c}}$, Giorgio Colombo ${ }^{\mathrm{c}}$, Geza Haidegger ${ }^{\mathrm{d}}$, Peter Kovacs ${ }^{\mathrm{d}}$ and Johan Stahre ${ }^{\mathrm{e}}$
}

a Department of Mechanical and Industrial Engineering, Tallinn University of Technology, Ehitajate tee 5, 19086 Tallinn, Estonia
b STIIMA-CNR, Institute of Intelligent Industrial Technologies and Systems for Advanced Manufacturing, National Research Council,
Milan, Italy
c Department of Mechanical Engineering, Politecnico di Milano, Milan, Italy
d SZTAKI - Institute for Computer Science and Control, Budapest, Hungary
e Department of Industrial and Materials Science, Chalmers University of Technology, Sweden

Received 15 June 2021, accepted 14 July 2021, available online 1 November 2021

(C) 2021 Authors. This is an Open Access article distributed under the terms and conditions of the Creative Commons AttributionNonCommercial 4.0 International License (http://creativecommons.org/licenses/by-nc/4.0/).

\begin{abstract}
The growing relevance of digitalization in production requires the enhancement of human skills and competences in the field of Information and Communication Technology (ICT). Higher education has to cope with this need by providing the necessary ICT skills to future industrial engineers, so that they have a good understanding of the complexity of industries in the 21 st century. This paper presents the conceptual development and testing of a Virtual Learning Factory Toolkit (VLFT) that integrates digital tools used in production management with engineering education. The digital tools integrated into the VLFT can help students to exploit enabling technologies such as simulation and virtual reality in their manufacturing studies and practical projects with industrial companies. Moreover, digital tools were tested by using a structured workflow that consists of different learning activities related to manufacturing system configuration. Students practised the digital tools with the help of use cases in the form of joint learning labs, after which the students' feedback was collected and analysed.
\end{abstract}

Key words: digital tools, production engineering, virtual learning factory, manufacturing systems.

\section{INTRODUCTION}

Manufacturing still plays a key role in modern economies because of its direct and indirect contribution to the Gross Domestic Product (GDP) generation [1]. Although there is recent development and growth in the service sector, international markets still insist on the importance of manufacturing in Europe and manufacturing remains a dominating factor in the total global trade with the contribution of $70 \%$ [2]. The current and prospective importance of manufacturing is analysed by several national and international institutions [3-4] showing

*Corresponding author, kashif.mahmood@taltech.ee how the technological development, its exploration and adaptation can be a key game-changer for the manufacturing industry.

Manufacturing faces the rapid evolution of enabling technologies, tools and techniques, in particular the advancements of Information and Communication Technology (ICT), also known as 'INDUSTRY 4.0' [5]. Therefore, there is a higher need for industrial workers and engineers that are trained in digitial technologies to properly cope with these changes. Higher education plays a vital role and is a major driver in building a skilled and knowledgebased workforce for the next generation manufacturing [6]. 
New learning schemes can be necessary for the training and professional development of workforce in this field, which is a challenge for the educational institutions. The concept of learning factories can contribute to establishing the relevant theoretical and practical knowledge about the new advancements [6,7]. Advanced learning labs are adopted by many educational institutions to cope with the challenges of digitalization in manufacturing and to learn new technological skills, knowledge and expertise in manufacturing $[8,9]$.

On the other hand, learning can be organized virtually by using digital tools to design, analyse, and visualize manufacturing processes and systems. Indeed, teaching in production engineering curricula can be effectively supported by creating virtual environments of a real production system or even a whole factory. Moreover, this kind of learning experience is even more relevant in the current pandemic of COVID-19 and its impact on educational institutions [10]. Virtual learning can take advantage of recent developments in the domain of virtual and digital factory $[11,12]$. Nowadays, several technical institutions and research centres are developing their own virtual factory tools or are enhancing existing software platforms and systems to develop optimization and control algorithms for factory simulation and visualizations. Nevertheless, these digital tools are mainly employed by scientists and practitioners involved in research activities while they are not easily accessible for teachers and students.

The purpose of this paper was to present a Virtual Learning Factory Toolkit (VLFT) framework that contains digital tools and use cases to be exploited by industrial engineering students. This framework was developed during an ERASMUS+ project [13] and provides digital tools to support the design, evaluation and visualization of manufacturing processes and systems. Moreover, it provides a workflow to guide the learning process that is applied to a use-case scenario of manufacturing system configuration. The approach was tested during joint learning labs involving different groups of students, where the digital tools were used and improvements suggested.

\section{VLFT FRAMEWORK AND WORKFLOW}

The VLFT framework (Fig. 1) provides a set of digital tools to support advanced engineering education in manufacturing. Currently, the framework includes digital tools to support the evaluation and design of production systems, their representation on a virtual reality environment, tools for the modelling of human operators. In addition, the VLFT grounds on a common knowledge base that consists of a data model and a data repository relying on semantic web technology [14].

\subsection{Digital tools and related activities}

In principle, any digital tool can be integrated into the VLFT framework if it is possible to access and modify its internal data structures (e.g., via exchange files or an API), thus creating data flows with the knowledge base (Fig. 1), possibly in an automated way. Currently, the VLFT offers the following digital tools that were selected because of free licence and ease of integration motivations:

- Java Modelling Tools (JMT) [15] for performance evaluation via discrete event simulation of production systems and respective Key Performance Indicators (KPIs) analysis, e.g., throughput, utilization, lead time, etc.;

- OntoGui [16], an ontology-based Graphical User Interface (GUI) for the definition of production system configurations in terms of part types, process plans,

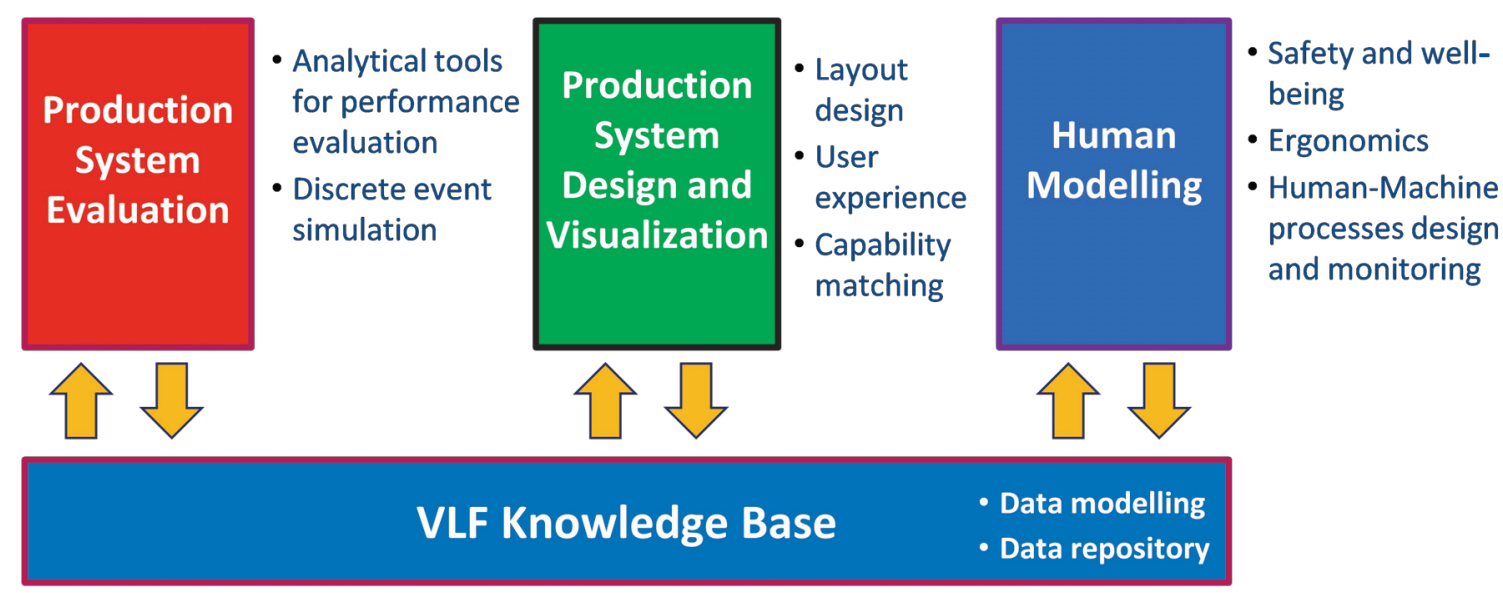

Fig. 1. VLFT framework. 
operations, assignment of operations to production resources (e.g., machine tools, transporters, storage systems) and connection between resources;

- Unity3D [17], VEB.js (Virtual Environment based on Babylon.js) [18] and ApertusVR-based applications [19] for the 3D visualization, animation and interaction with production systems and resources via virtual reality.

These digital tools can support different business processes along a production system lifecycle, both in industrial applications and, above all, in a teaching context. The adoption of these digital tools enables the application of complex engineering approaches such as simulation and analytical performance evaluation, which can assist in reaching a set of learning objectives and improve the students' learning effectiveness.

The VLFT knowledge base and digital tools are documented in the online guidelines to foster the reuse in new teaching contexts [20].

\subsection{Workflow for practising digital tools}

A VLFT workflow is a sequence of steps to address relevant manufacturing engineering problems while taking advantage of the integrated digital tools. Workflows can be applied to specific case studies with the aim of improving the learning effectiveness of engineering students. Four different workflows have been designed taking into consideration manufacturing problems at different levels of detail and from different perspectives:
- Manufacturing system (re-)configuration;

- Process-System design and analysis;

- Humans in manufacturing;

- Manufacturing system monitoring.

Each workflow is designed as a three-layer structure illustrated in Fig. 2 while considering a generic workflow. The first layer describes a sequence of steps (activities), starting from the formalization and modelling of the problem under study, to the definition of the final solution, passing through design and analysis steps. For each step, the Intended Learning Outcomes (ILOs) [21] are declared to describe what students should learn and be able to do at the end of the learning activity. Finally, ILOs are linked to proper digital tools whose utilization can help to reach them.

The following section delves into the workflow of manufacturing system (re-)configuration.

\section{CASE STUDY OF MANUFACTURING SYSTEM CONFIGURATION}

The configuration of a manufacturing system is a key activity since the decisions to be taken have a long-term impact on the lifecycle of the system under study. Starting from a set of requirements in regard to capability and capacity, the pieces of equipment and their arrangement must be analysed to find the best configuration solution, for example, minimizing the equipment cost (under performance constraints). This may require the evaluation

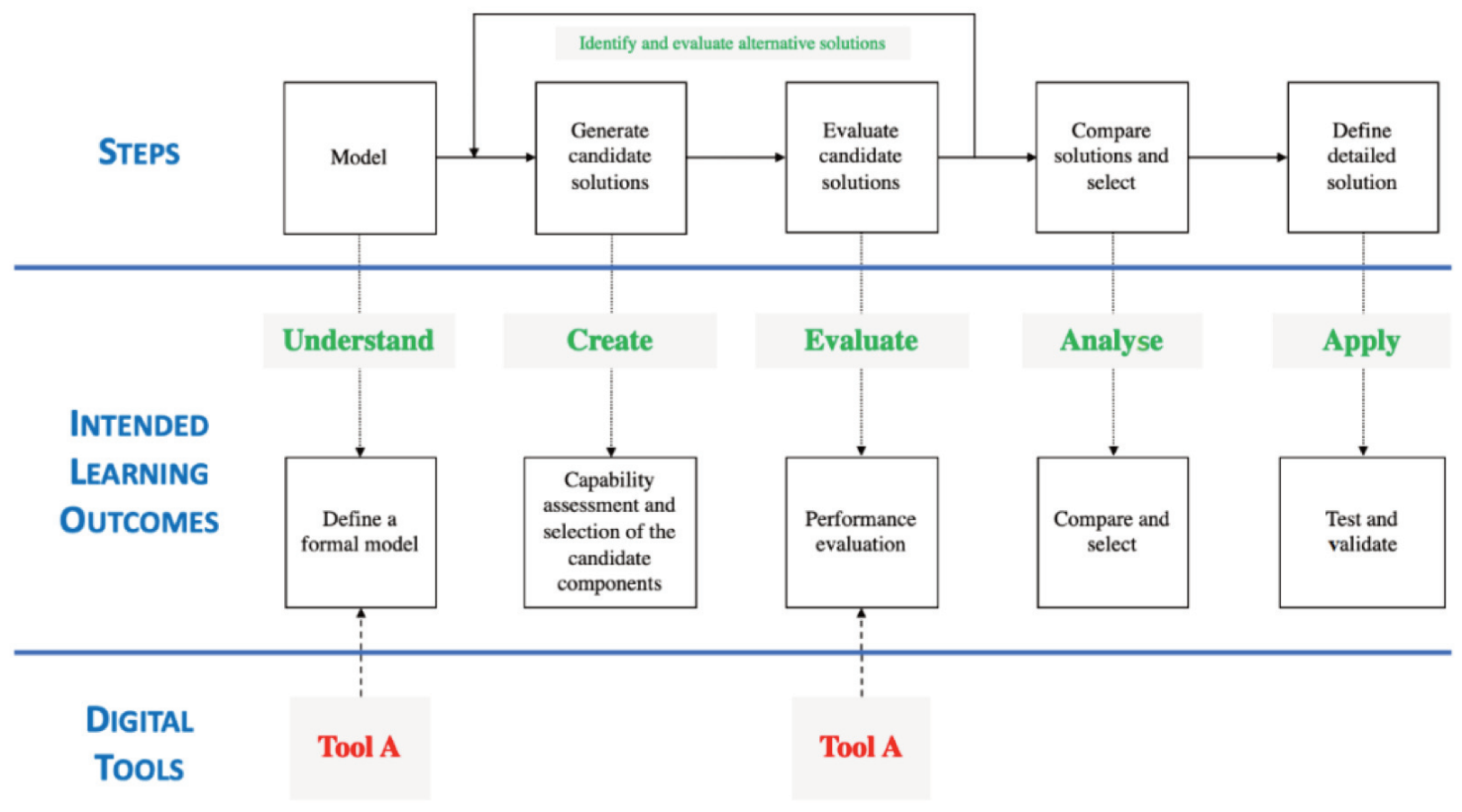

Fig. 2. Structure of a workflow. 
and analysis of a very large number of alternative configurations.

\subsection{Workflow for the case study}

The configuration and re-configuration process can be described in terms of a sequence of steps, starting from the modelling of a hypothetical system or the existing one (in case of re-configuration) and ending in the virtual commissioning where the selected best solution is validated and tested.

The first step entails the modelling of the system under study. In the case of green-field design, this modelling needs some basic decisions, for example, the adopted architecture (job shop, flow shop, etc.), the class of transportation schemes and routes, etc. In the case of a re-configuration, this modelling phase is devoted to providing a formal representation of the existing system and the associated constraints.

Once the modelling phase has been completed, the configuration workflow proceeds to the selection of the pieces of equipment. Then, a set of candidate solutions are generated by composing the pieces of equipment in different alternative configurations. These two tasks have to take as input the characteristics of the products to be produced, the associated production process, the resource capabilities and the requirements in terms of volumes, flexibility, etc. The final output is the formal representation of the candidate system configurations to be further analysed. During the execution of these steps, backtracking actions can be operated to modify/improve the selected candidate configuration grounded on the assessment of the associated capability.

The candidate configurations are evaluated in regard to production performance. Analytical methods can be used to quickly evaluate and possibly reduce the set of can- didate configurations. Then, Discrete Event Simulation (DES) approaches can provide a more detailed evaluation.

After these two performance evaluation steps, the candidate solutions are transformed in detailed layouts to assess them in a $3 \mathrm{D}$ virtual reality environment. Finally, the best solution(s) is (are) selected.

\subsection{Description of use cases}

The first use case is related to the process of filling, labelling and capping the bottles. The layout of the production line shown in Fig. 3 is composed of one pallet place providing boxes at the beginning of the line and one pallet place waiting for boxes at the end of the line. A conveyor moves the bottles through the sequence of labelling machine, filling machine and capping machine. At the end of the line, there is a storage plate where the filled bottles are put into the empty boxes. The transportation of pallet is executed by one Automated Guided Vehicle (AGV) while two workers execute the operation of box opening/packing and positioning of bottles, at the beginning and at the end of the line respectively.

The second use case is related to a flexible manufacturing system consisting of three main modules: storage, transportation via mobile robot and machine tending. The entire system is highly automated and there is no manual activity during the whole production cycle. The manufacturing system can be seen in Fig. 4 and the process flowchart is reported in Fig. 5.

\subsection{Testing of tools in joint learning labs of students}

The developed workflow for manufacturing system configuration and the identified digital tools in the VLFT were tested by students during the joint learning labs

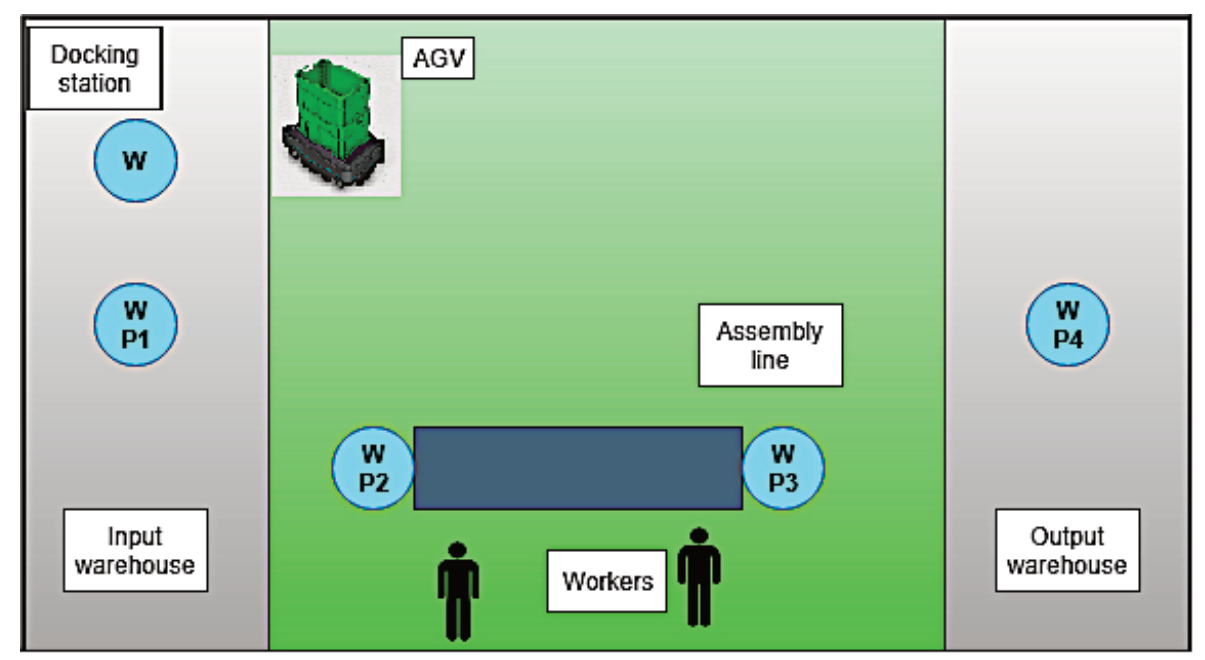

Fig. 3. Use case I - production floor layout. 

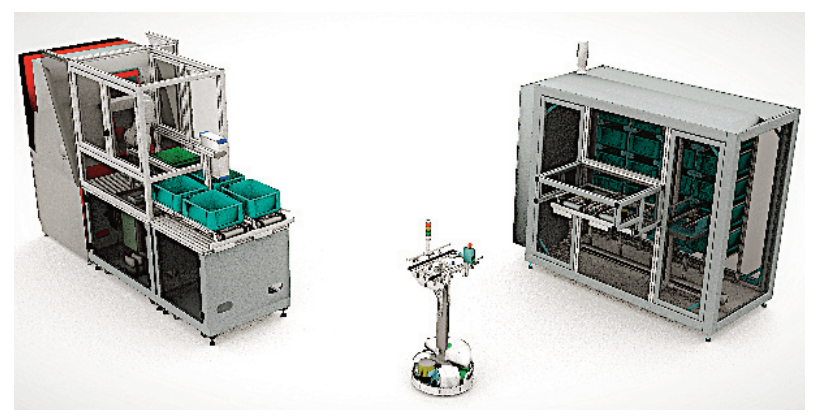

Fig. 4. Use case II - flexible manufacturing system.

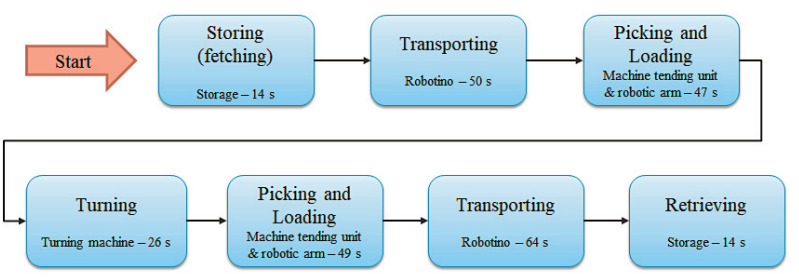

Fig. 5. Process flow of flexible manufacturing system.

organized by the ERASMUS+ VLFT project. The first joint learning lab was held onsite, but the following ones were organized online due to Covid-19 restrictions. The purpose of the joint learning lab was to develop and test the set of identified digital tools, and improve these tools through students' feedback. In the workshops, 15 students from three institutes were involved. Tutors and evaluators from project partners also participated in the workshop.

The development, learning and testing of the digital tools were practised in two phases. During the first phase, students worked independently at their home institutes. In the second phase they were involved in the joint learning lab and were asked to work together by exchanging information, improving their skills and learning from each other. The students were divided into mixed groups considering the technical skills and the activities they already addressed. Each group was assigned a specific use case while adopting the reference workflow and the following main steps:

(a) Formal modelling and defining production (assembly) processes of use cases by using OntoGui (see Fig. 6);

(b) DES for performance evaluation by using JMT. Prepared a procedure for the automatic generation of a DES model using JMT, starting from the model developed with OntoGui for both use cases (see Fig. 7);

(c) 3D modelling, visualization and animation for products and systems associated with the use cases. 3D scenes were generated via Unity3D and VEB.js (see Fig. 8), CAD models were created through solid modelling software and open source libraries. The animated output was visualized by means of Virtual Reality (VR).

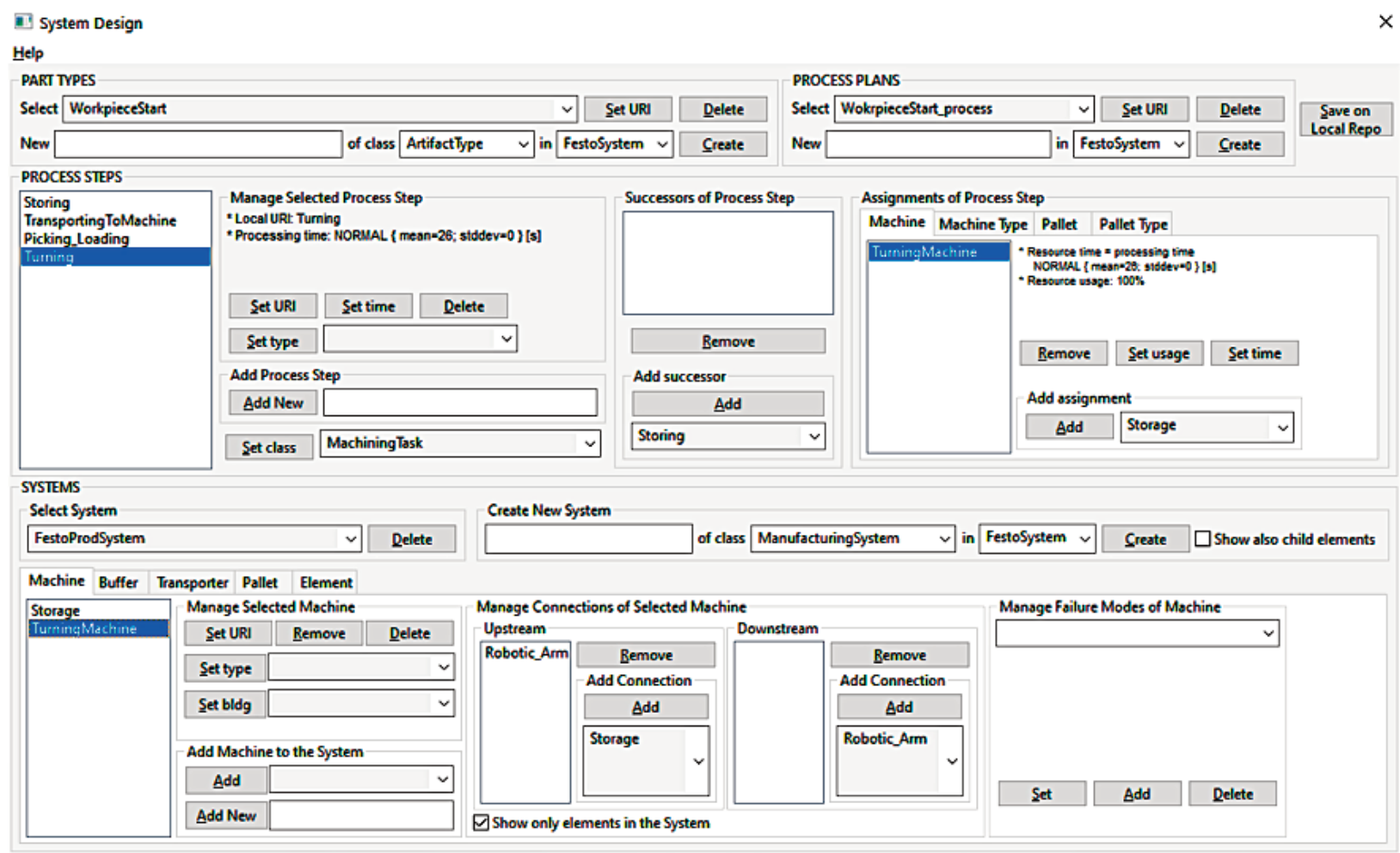

Fig. 6. Use cases' description via OntoGui. 


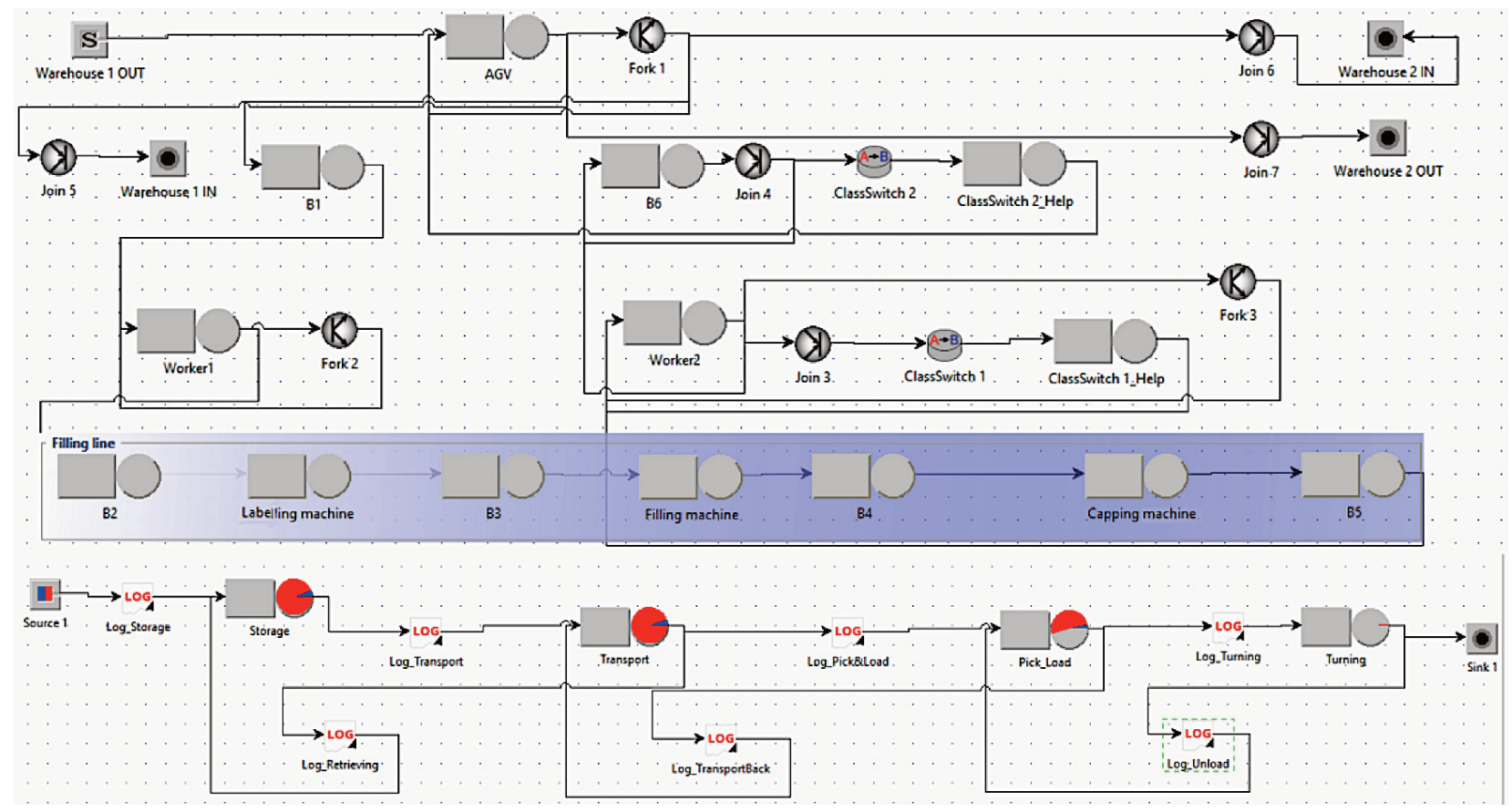

Fig. 7. Use cases' model via JMT.

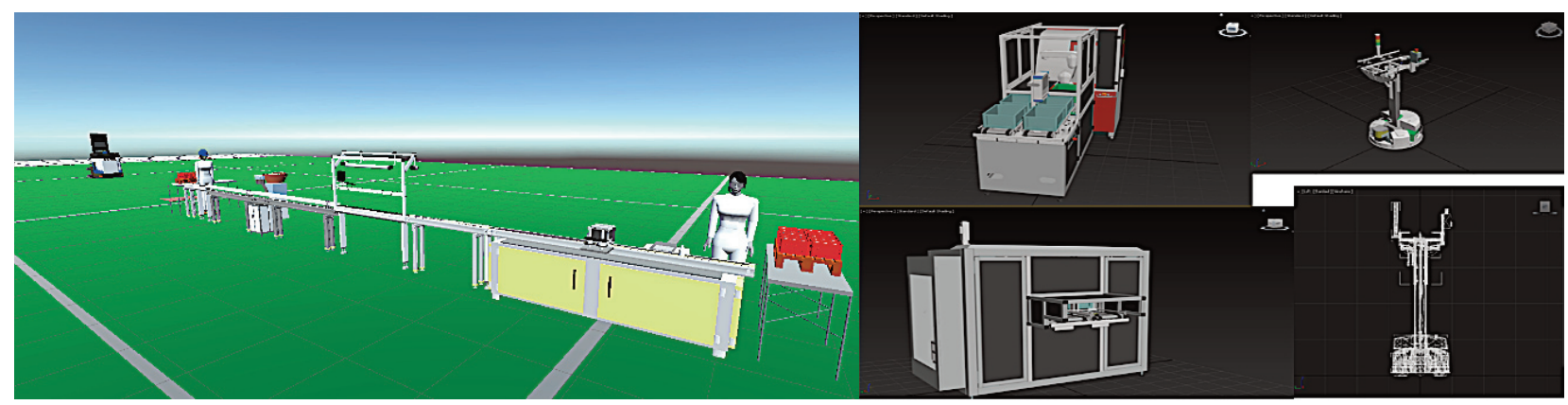

Fig. 8. Use cases' model via Unity3D and VEB.js.

Some concluding observations can be drawn about the students' work: pros - the background of all the students was sufficient to support activities related to the virtual representation of the addressed use cases, whose results were in line with the expectation as well as with the constraints due to the available time; cons - the background knowledge related to the formal representation of the use case was not sufficient to support all the activities. Thus, the development of simulation models and the integration between digital tools requires additional learning steps to be carried out in advance.

\section{STUDENTS' FEEDBACK}

After each joint learning lab, the students' feedback was collected through a survey. Herein, we report the results after the first and third joint learning labs.

\subsection{Students' feedback for onsite (1st) joint learning lab}

The survey consisted of questions related to the experience and learning outcome:

(a) General appreciation for the workshop;

(b) Learning ability;

(c) Learning level reached;

(d) Self-evaluation.

The results of the survey are reported in Fig. 9, where the satisfaction of the students is expressed on a 1-5 scale: $1=$ Very dissatisfied, $2=$ Dissatisfied, $3=O K, 4=$ Satisfied, 5 = Very satisfied.

Overall, it can be concluded that the student workshop was satisfactory. Students have learned, contributed to and tested the digital tools and methods. However, there were a few shortcomings, e.g. in the learning outcomes of the digital tools used with respect to workflow definition, 


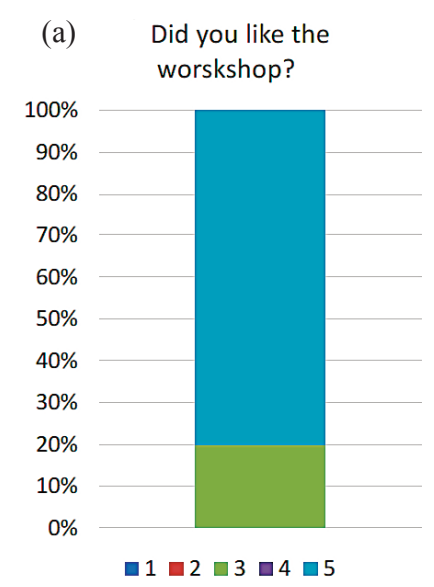

(c) Evaluation of the reached learning level of methods and digital tools related to

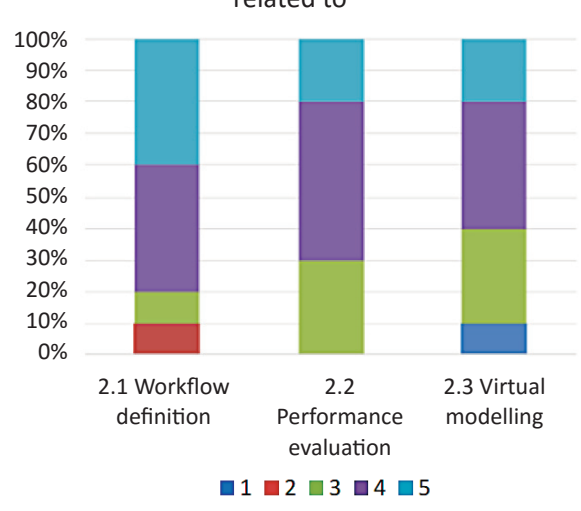

(b) Evaluate your learning ability through
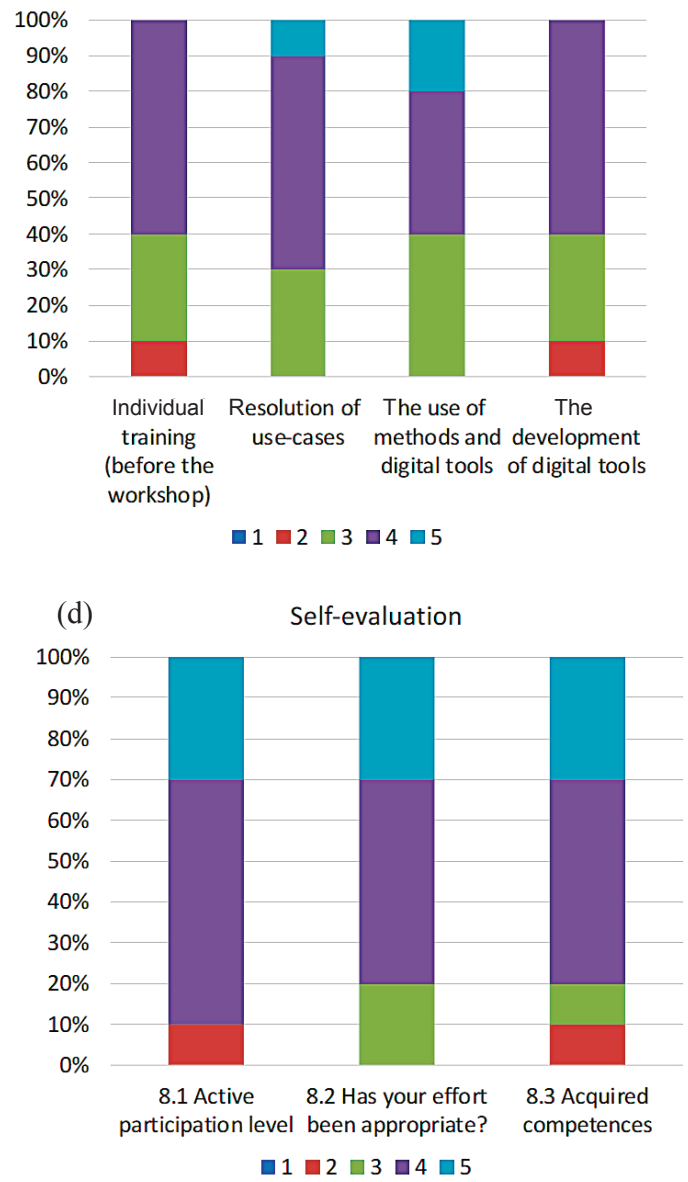

Fig. 9. Graphical representation of students' feedback about the onsite (1st) workshop.

performance evaluation and virtual modelling. It was also observed that there were some missing competences related to programming and the integration of digital tools. Moreover, communication and cooperation skills were considered as very necessary aspects in the teamwork.

\subsection{Students' feedback for online (3rd) joint learning lab}

The 3rd students' workshop was carried out online and it accomplished the planned activities. The feedback of the students was collected through a questionnaire, which was based on but not limited to the following elements:

- Ability to learn;

- Ability to achieve your goals;

- Model production system by structured approach;

- Overall, satisfied with the quality of this learning lab. The results of the online students' workshop are reported in Fig. 10 and expressed on a 1-5 scale: $1=$ Disagree, $2=$ Somewhat disagree, $3=$ Neutral, $4=$ Somewhat agree, $5=$ Strongly agree.
It can be commented that the students have achieved learning objectives related to the use of digital tools for modelling manufacturing systems, with different levels of competence, and they have experienced interesting collaboration among different institutions. However, according to the feedback provided by the students, the online organization of the workshop was a significant barrier to discussion and collaboration, compared to meeting in person. Indeed, online meetings were not helpful to start the collaboration among students because of ineffective communication and coordination.

\section{CONCLUSIONS}

The development of Virtual Learning Factory Toolkit is a contribution to modern learning in manufacturing engineering education. This research has presented the framework of the VLFT together with candidate digital tools, possible learning activities and workflows designed to test the improvement of ICT skills in manufacturing 

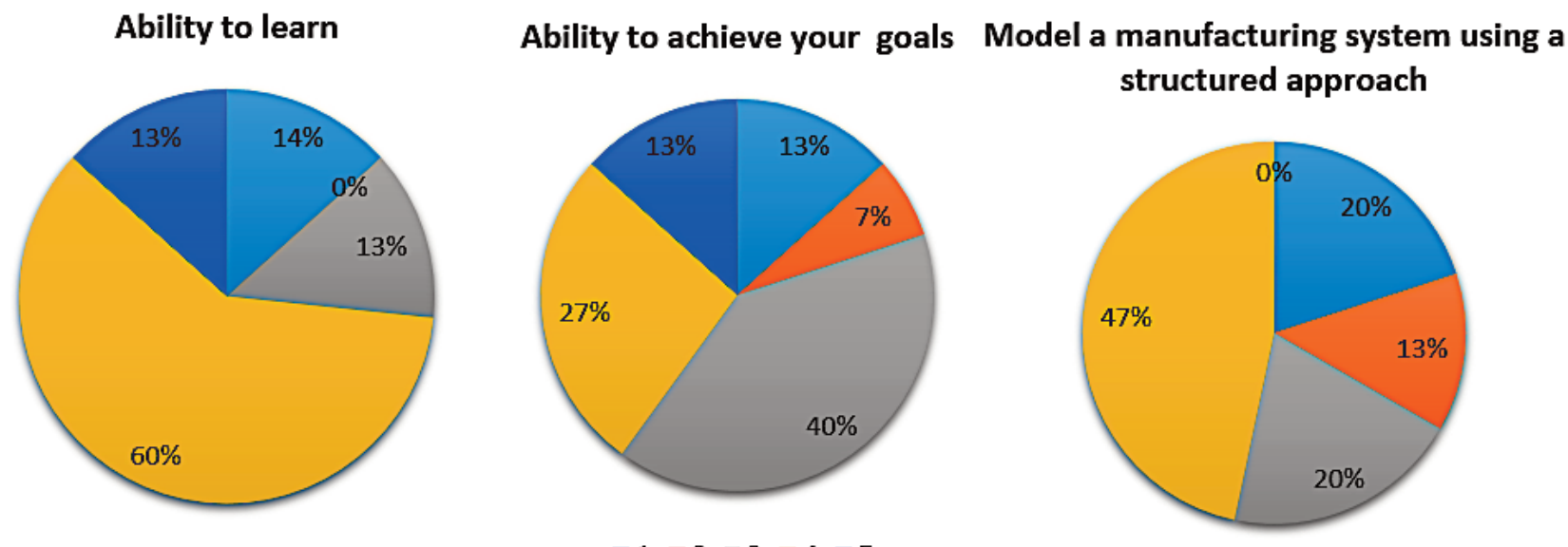

$\square 1 \square 2 \square 3 \square 4 \square 5$

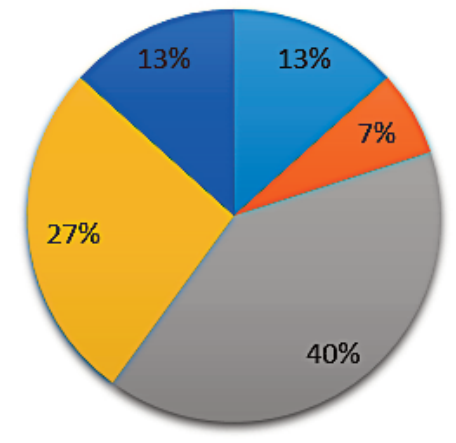

$\square 1 \square 2 \square 3 \square 4 \square 5$

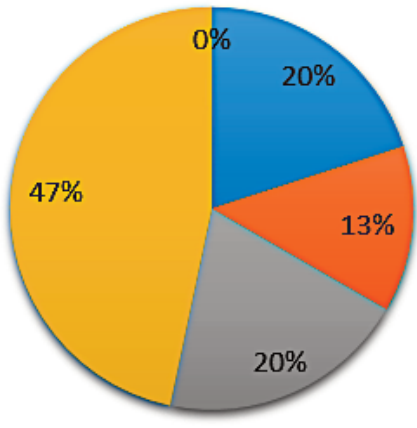

$\square 1 \square 2 \square 3 \square 4 \square 5$

\section{Overall, I was satisfied with the quality of this learning lab}

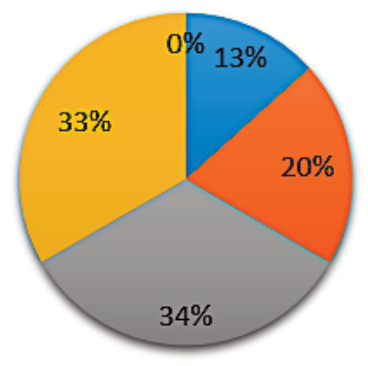

$\square 1 \square 2 \square 3 \square 4 \square 5$

Fig. 10. Graphical representation of students' feedback about the online (3rd) workshop.

curricula. The selected and tested digital tools facilitate the definition, performance evaluation, visualization of production systems and related processes in a digital environment thanks to 3D simulations and virtual reality technologies. Thanks to the VLFT, it was possible to improve ICT skills of teachers and students, promote better understanding of the actual processes and production management. The tools and related learning activities were tested during joint learning labs, leading to a positive experience that helped to validate the development of digital tools and showed a way to improve the VLFT in the future. In particular, further developments will be focused on a better integration of digital tools.

\section{ACKNOWLEDGEMENTS}

This study was part of the ERASMUS+ VLFT project and it was supported by ERASMUS+ program. The authors are thankful to the students and mentors from TALTECH, POLIMI, CNR-STIIMA and SZTAKI, who participated in the workshop and provided a valuable feedback. The publication costs of this article were covered by the Estonian Academy of Sciences and Tallinn University of Technology.

\section{REFERENCES}

1. Terkaj, W. and Tolio T. The Italian flagship project: factories of the future. In Factories of the Future (Tolio, T., Copani, G. and Terkaj, W., eds). Springer, Cham, 2019, 3-35.

2. World Trade Organization (WTO). World Trade Statistical Review 2018. https://www.wto.org/english/res_e/statis_e/ statis_e.htm

3. Storrie, D. The future of manufacturing in Europe. Eurofound, 2019. http://eurofound.link/fomeef18002

4. Kangru, T., Riives, J., Mahmood, K. and Otto, T. Suitability analysis of using industrial robots in manufacturing. Proc. Est. Acad. Sci., 2019, 68(4), 383-388.

5. Mahmood, K., Karaulova, T., Otto, T. and Shevtshenko, E. Development of cyber-physical production systems based on modelling technologies. Proc. Est. Acad. Sci., 2019, 68(4), 348-355. 
6. Abele, E., Chryssolouris, G., Sihn, W., Metternich, J., ElMaraghy, H., Seliger, G. et al. Learning factories for future oriented research and education in manufacturing. CIRP Ann. Manuf. Technol., 2017, 66, 803-826.

7. Wagner, U., AlGeddawy, T., ElMaraghy, H. and Müller, E. The state-of-the-art and prospects of learning factories. Procedia CIRP, 2012, 3, 109-114.

8. Baena, F., Guarin, A., Mora, J., Sauza, J. and Retat, S. Learning factory: the path to Industry 4.0. 7th Conference on Learning Factories. Procedia Manuf., 2017, 9, 73-80.

9. Tvenge, N. and Ogorodnyk, O. Development of evaluation tools for learning factories in manufacturing education. 8th Conference on Learning Factories. Procedia Manuf., 2018, 23, 33-88.

10. Pokhrel, S. and Chhetri, R. A literature review on impact of COVID-19 pandemic on teaching and learning. High. Educ. Future, 2021, 8(1), 133-141.

11. Caggiano, A. and Teti, R. Digital factory technologies for robotic automation and enhanced manufacturing cell design. Cogent Eng., 2018, 5(1), 1-14.

12. Terkaj, W., Gaboardi, P., Trevisan, C., Tolio, T. and Urgo, M. A digital factory platform for the design of roll shop plants. CIRP J. Manuf. Sci. Technol., 2019, 26, 88-93.
13. Virtual Learning Factory Toolkit (VLFT). TalTech, 2020. https://www.vlft.eu

14. Urgo, M. and Terkaj, W. Formal modelling of release control policies as a plug-in for performance evaluation of manufacturing systems. CIRP Ann. Manuf. Technol., 2020, 69(1), 377-380.

15. Bertoli, M., Casale, G. and Serazzi, G. JMT: performance engineering tools for system modelling. ACM SIGMETRICS Perform. Evaluation Rev., 2009, 36(4), 10-15.

16. Terkaj, W. OntoGui: A graphical user interface for rapid instantiation of OWL ontologies. CEUR Workshop Proc., 2017, 2050.

17. Unity. Unity Technologies, 2021. https://unity.com

18. Virtual Learning Factory Toolkit. VEB.js., 2021. https:// virtualfactory.gitbook.io/virtual-learning-factory-toolkit/tools/ vebjs

19. ApertusVR. http://apertusvr.org

20. Virtual Learning Factory Toolkit. GitBook, 2021. https:// virtualfactory.gitbook.io/virtual-learning-factory-toolkit

21. Spronken-Smith, R., Walker, R., Batchelor, J., O'Steen, B. and Angelo, T. Evaluating student perceptions of learning processes and intended learning outcomes under inquiry approaches. Assess. Eval. Higher Educ., 2012, 37(1), 57-72.

\section{Tootmisinseneride hariduse edendamine virtuaalse õppetehase tööriistakomplekti kontseptsiooni kaudu}

\section{Kashif Mahmood, Tauno Otto, Vladimir Kuts, Walter Terkaj, Gianfranco Modoni, Marcello Urgo, Giorgio Colombo, Geza Haidegger, Peter Kovacs ja Johan Stahre}

Digitaliseerimise kasvav tähtsus tootmises nõuab info- ja kommunikatsioonitehnoloogia (IKT) osas töötajate oskuste ning pädevuste parendamist. Kõrgharidus peab selle vajadusega toime tulema, pakkudes tulevastele tööstusinseneridele vajalikke IKT-oskusi, andmaks neile hea arusaama 21. sajandi tööstuse keerukusest. Käesolevas artiklis on tutvustatud virtuaalse õppetehase tööriistakomplekti (VLFT) kontseptsiooni väljatöötamist ja katsetamist, kus on ühendatud tootmise juhtimises ning inseneriõppes kasutatavad digitaalsed tööriistad. VLFT-sse integreeritud digitaalsed tööriistad aitavad õppuritel kasutada tootmisalastes õpingutes ja tööstusettevõtetele suunatud praktilistes projektides digitehnoloogiaid, nagu simulatsioon ning virtuaalne reaalsus. Lisaks testiti digitaalseid tööriistu, kasutades struktureeritud töövoogu, mis koosneb tootmissüsteemi konfiguratsiooniga sidustatud eri õppetegevustest. Õppurid praktiseerisid kasutamisjuhtumite abil uudseid digivahendeid ühistes virtuaalõppelaborites, seejärel koguti ja analüüsiti õppurite tagasisidet. 